RECORDS OF PHARMACEUTICAL
AND BIOMEDICAL SCIENCES

\title{
A Brief review of Circulating MicroRNAs and Essential
}

\section{Hypertension}

\author{
Heba K. Badawy ${ }^{a}$, Noha M. Mesbah ${ }^{b}$, Dina M. Abo-Elmatty ${ }^{b}$, \\ Faculty of Pharmacy, Department of Biochemistry, Sinai university, El-Arish, North Sinai ${ }^{b}$, Faculty of \\ Pharmacy, Department of Biochemistry, Suez Canal University, Ismailia, Egypt.
}

Received on: 30.10.2018

Revised on: 25.11.2018

Accepted on: 30.11.2018

*Corresponding Author:

Business Tel:

$+2-01223729408$

E-mail:

heba_kamel20@yahoo.com

\begin{abstract}
Essential hypertension is a chronic medical condition affecting thousands of people worldwide. It is polygenic and multi-factorial disease resulting from the interaction between genetic and environmental factors. Essential hypertension is implicated in cerebrovascular, cardiovascular and renal diseases. MicroRNAs are considered endogenous, non-coding regulators of gene expression by targeting specific mRNAs for degradation and/ or translational repression. MicroRNAs participate in a variety of developmental processes as metabolism, cell proliferation, and apoptosis. Many studies have reported the possibility of using miRNAs as new biological markers for polygenic diseases as cancer, stem cell aging, coronary heart disease, and essential hypertension. The stability of these miRNAs as miRNA let-7e, miRNA 296-5p, miRNA 605, and miRNA 623 in biological fluids makes them amenable to detection and quantification. This review summarizes the mechanisms by which miRNAs can control normal cellular processes and gene expression and the association of some circulating miRNAs with the incidence of different diseases, particularly essential hypertension.
\end{abstract}

Keywords:Essential hypertension, microRNA Let-7e, miRNA 296-5p miRNA 605, miRNA 623.

\section{Introduction}

MicroRNAs (miRNAs) were first reported as a single stranded non-coding RNA molecule, lin-4, in the organism Caenorhabditis elegans (Lee et al., 1993). Later on, the regulation of a key gene by lin-4 was reported. Lin-4 was described as a temporal gene regulator, controlling the time of development stages in C. elegans
(Lee and Ambros, 2001). A second miRNA, let-7, was described in the year 2000 (Reinhart et al., 2000). The prevalence of let-7 was evaluated across numerous species (Pasquinelli et al., 2000). Since then, hundreds of miRNAs have been identified in organisms ranging from viruses, plants, flies, fish, frogs, and mammals, including humans (Miska et al., 2007).Thus, miRNAs were recognized as important regulators of gene expression. More than 
1000 microRNA genes were identified in the human genome (Kozomara and Griffiths-Jones, 2011). MiRNAs are the most prevalent class of small RNAs in animals (Farazi et al., 2008).

\subsection{MiRNA biogenesis}

MicroRNA production is endogenously regulated by their target genes, which are located throughout the genome. About $50 \%$ of miRNAs are expressed from intergenic, non-protein-coding regions, while others are encoded in intra-genic regions within the intronc regions (Lagos-Quintana et al., 2001). Some miRNA genes are clustered together in the genome and transcribed as poly-cistronic miRNA transcripts. Clustered miRNAs have a high degree of sequence similarity. Regulation of miRNA biosynthesis is a multistep process that starts in the nucleus of the cell, and continues in the cytoplasm until the mature miRNA can exert its function (Thum et al., 2007), ( Figure 1).The sequence of this process is as follows:

1. MiRNAs are transcribed by RNA polymerase II as a primary miRNA (pri-miRNA) transcript that is capped by polyadenylation (Bartel, 2004).

2. The long transcript "hairpin structure", primiRNA, is recognized and cleaved by a multiprotein complex (microprocessor). The core component of this microprocessor is called DROSHA ( an RNase III), and its associate DGCR8 (DiGeorge syndrome critical region gene 8, a double stranded RNA-binding domain protein), cleave pri-miRNA to a 60-70nucleotide stem-loop structure, called precursor miRNA (premiRNA) (Zeng and Cullen, 2003).

The Drosha- cleavage process is controlled by RNA binding proteins including the DEAD box RNA helicases p68 (DDX5) and DEAD box RNA helicases p72 (also known as DDX17), as well as heterogenous ribonucleoproteins (hnRNPs) (Gregory et al., 2004).

Without the DEAD box RNA helicases, Drosha cannot generate pri-miRNA (Fukuda et al, 2007).

3. Drosha cleavage product, pre- miRNAhas $2 \mathrm{nt}$ $3^{-}$overhang that is recognized by Ran-GTP and exportin-5 (XPO5) minor export factor, which transport the pre- miRNA into the cytoplasm
(Okada et al., 2009).

4. The exported pre-miRNA is processed in the cytoplasm to a duplex 22 nucleotides large. The premiRNA is cleaved again by a cytoplasmic RNase III called Dicer together with Trans -activator RNA (tar)binding protein (TRBP) (Knight and Bass, 2001). Dicer has a single processing center with two dimerized RNase III domains. Each RNase domain independently cuts one RNA strand of the duplex and generates products with 2 nucleotide $3^{\prime}$ overhangs (Figure 1) (Filipowicz, 2005).

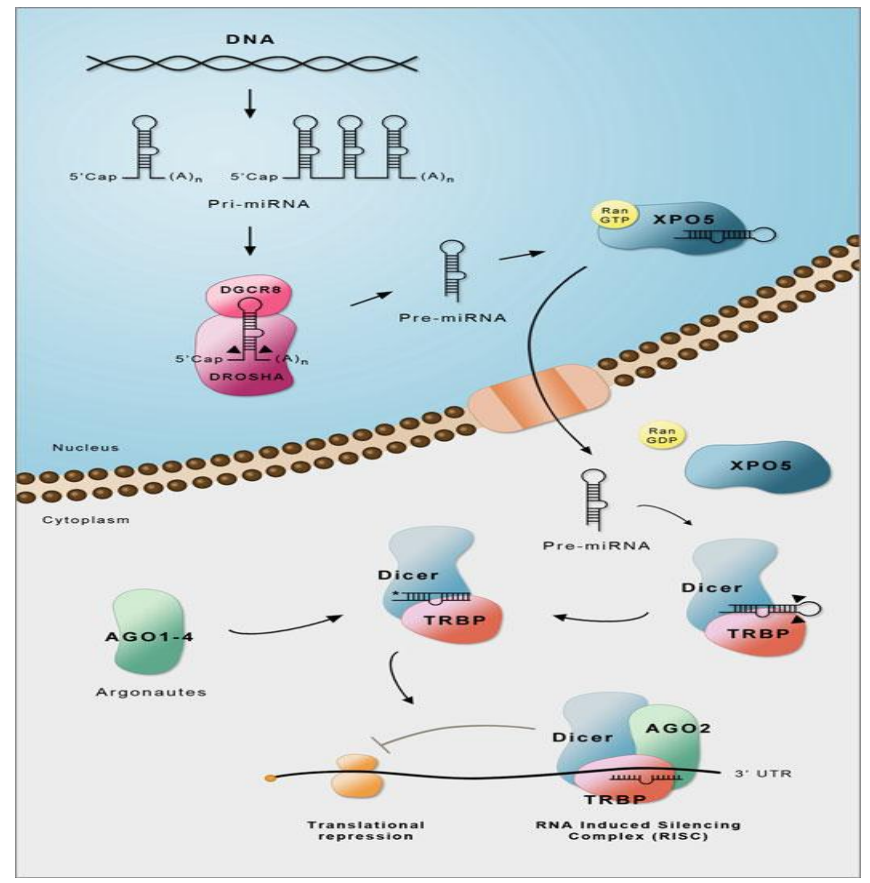

Figure 1.Biogenesis of miRNAs. Ago2, Argonaute; DGCR8, DiGeorge syndrome critical region gene 8;DROSHA, RNase III enzyme; RISC, RNA-induced silencing complex; pre-miRNA, precursor miRNA; primiRNAs, long primary transcripts; TRBP, TARbinding protein; XPO5, exportin-5 (Thum et al., 2007).

5. The resulting new RNA duplex is loaded on Argonaute-2 protein (AGO2) generating the effector complex, RNA induced silencing complex (RISC). RISC is the cytoplasmic effector form of the miRNA pathway and contains a single-stranded miRNA which is ready to guide it to its target mRNAs. The RISC loading complex (RLC) is formed. It is a multi-protein complex composed of Dicer, TRBP, HIV-1 trans activating response (TAR) RNA binding protein and the core component AGO2. The mature miRNA remains bound to the AGO protein. 


\subsection{Mechanism of action of miRNAs}

MiRNAs regulate gene expression by binding with complementary sequences of the 3' untranslated region (UTR) of targeted mRNAs, resulting in either translational suppression or transcript degradation (Buchan and Parker, 2007) (Figure 2). The mechanism of action depends on how much the miRNA forms a perfect Watson Crick pair with its target mRNA, which is achieved by two mechanisms. In the first mechanism (cleavage mechanism), miRNA is in a perfect or nearly perfect Watson-Crick pair with the target mRNA. The mature miRNA is loaded into RISC with TRBP and protein activator of protein kinase (PACT). Then, the AGO-2 endonuclease activity in RISC cleaves the passenger strand of the mature RNA, and miRNA single strand along with RISC complex targets the mRNA for degradation (Martinez et al., 2002) (Figure 3).

In the second mechanism, the sequences of miRNA and target mRNA are not completely complementary. Translational repression occurs by a bypass mechanism, which requires a helicase activity to unwind and discard the miRNA strand, rather than directly cleave the mRNA strand by AGO-2. Once the miRNA strand has been unwound or discarded, the RISC causes translational suppression. At least $60 \%$ of protein encoding genes are regulated by miRNAs (Bartel, 2009), and the same miRNA can regulate different mRNAs.

\subsection{Functions of miRNAs}

MiRNAs are involved in many biological processes, such as cell differentiation, cell proliferation, cell migration, apoptosis, metabolism, and cell defense (Zhang, 2009). They are also involved in development of malignancies and cardiovascular diseases (Ha, 2011). Expression of some miRNAs is tissue-specific (Lagos-Quintana et al., 2002); miR-1, miR-122, and miR-124 are expressed in the heart, liver, and brain, respectively.

\section{Circulating miRNAs}

Some miRNAs are extremely stable in extracellular fluids as blood plasma, serum,

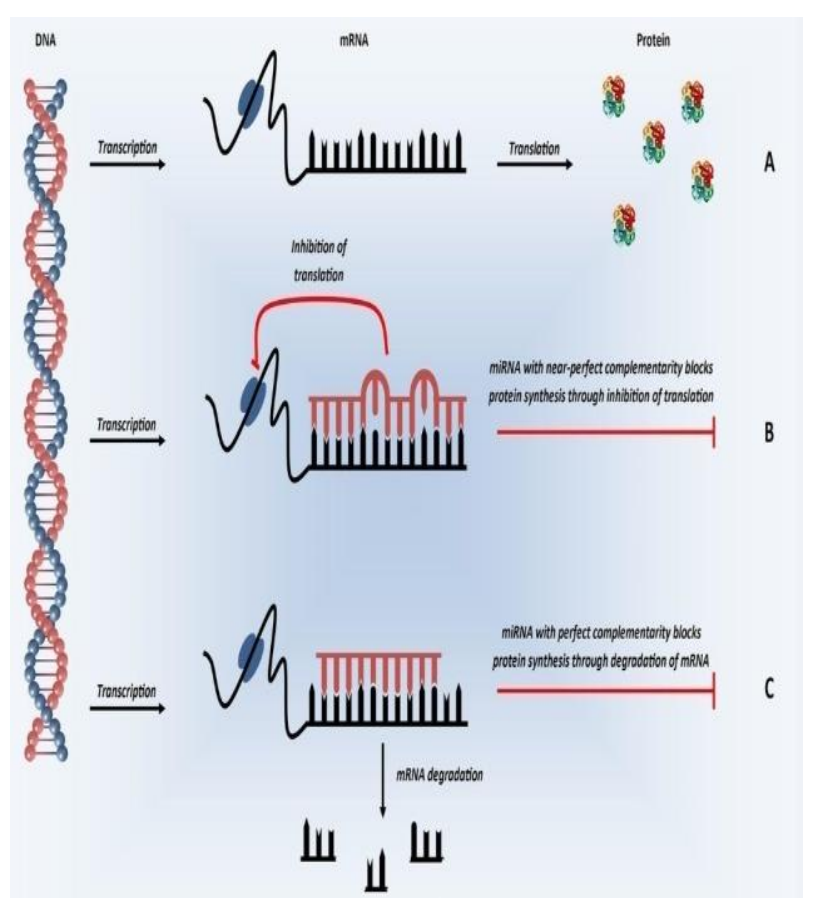

Figure 2. Schematic representation of microRNA mechanism of action (Romaine et al., 2015)

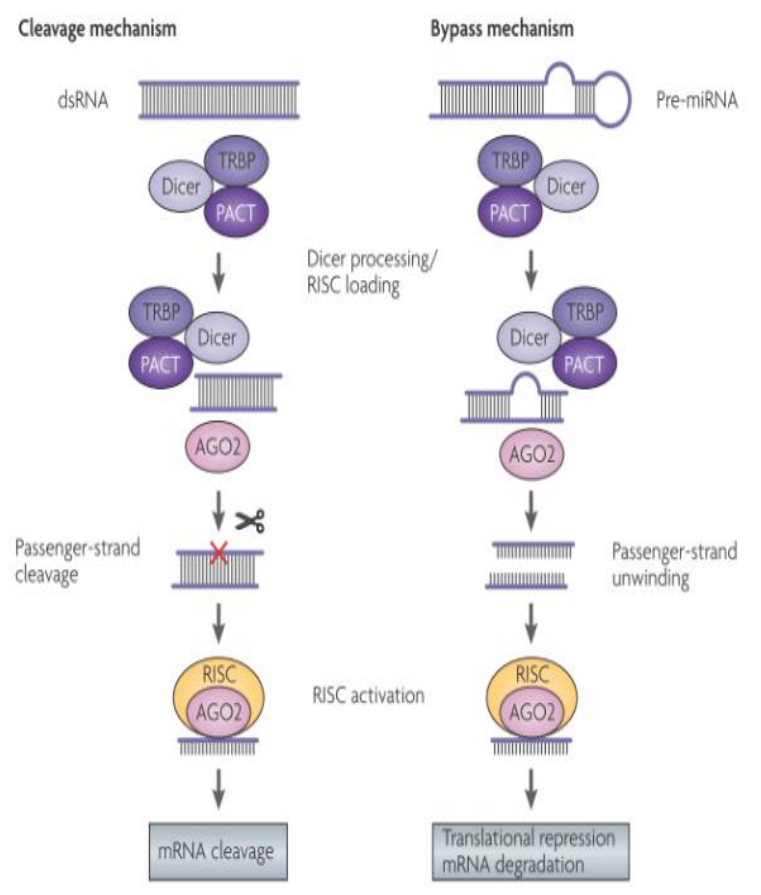

Figure 3. Mechanisms of how miRNAs mediate gene silencing: cleavage and translational suppression (Kim and Rossi, 2007). 
urine, saliva, and semen (Weber et al., 2010). The stability of miRNAs in plasma or serum makes it easy to use them as potential biomarkers for detection, diagnosis, and prognosis of diseases. Circulating miRNAs are stable despite the action of ribonucleases. It has been suggested that miRNAs are included into microparticles to protect them from degradation. Microparticles can be exosomes, microvesciles or apoptotic bodies (El-Hefnawy et al., 2004). HDL is also a transporter for endogenous miRNAs (Vickers et al., 2011).

Active release of circulating miRNAs may support their actions as "hormones" in cell-to-cell communication. Plasma levels of miRNAs usually become dysregulated before physical symptoms of disease appear, making them acceptable biomarkers (Romaine et al., 2016).

The potential for using circulating miRNAs as noninvasive, plasma-based biomarkers for detection of disease has been researched and has opened up a field in the monitoring and screening of cardiovascular diseases including hypertension (Nemecz et al., 2016).

\subsection{MiRNAs and diseases}

Since miRNAs alter gene expression, studies have examined the association between miRNAs and initiation and progression of many diseases. The Human MicroRNAs Disease Database lists miRNAs implicated with diseases (Table 1).

\subsubsection{MiRNAs and essential hypertension}

MiRNAs are implicated directly and indirectly in the pathogenesis of essential hypertension (Nadar et al., 2006).

\subsubsection{1. miRNAs that target vascular endothelium}

The vascular endothelium contributes to the pathogenesis of hypertension by many mechanisms. In the hypertensive patient, high blood pressure leads to activation of endothelial cells, the release of inflammatory and pro-coagulant mediators, and the adherence of neutrophils and platelets. As a result, the endothelium becomes dysfunctional, leading to impaired vasodilatation and a proinflammatory and pro-thrombic phenotype of the vessel wall.
(Landmesser and Drexler, 2007).

Endothelial dysfunction and defective angiogenesis are due to defective vascular endothelial growth factor (VEGF) signaling. MiRNA 126 is an effective factor for vascular integrity and angiogenesis. Furthermore, targeted deletion of miRNA 126 was associated with leaky vessels and hemorrhage (Wang et al., 2008), through controlling of endothelial response to VEGF. In another study, miRNA 21 was shown to inhibit angiogenesis by decreasing RhoB expression at endothelial cells (Sabatel et al., 2011).

Table 1. Association of miRNAs with common pathologies (Li and Kowdley, 2012).

\begin{tabular}{|c|c|c|}
\hline Disease & MiRNA & References \\
\hline Alzheimer's disesse & $\begin{array}{c}\operatorname{miR} 9, \operatorname{miR} 29 \\
\operatorname{miR}, 146, \operatorname{miR} \\
107\end{array}$ & $\begin{array}{l}\text { (Li and } \\
\text { Kowdley, } \\
\text { 2012) } \\
\text { (Esteller, } \\
\text { 2011) }\end{array}$ \\
\hline Arrhythmia & $\operatorname{miR}, 1, \operatorname{miR}, 133 a$ & $\begin{array}{c}\text { (Hedley et al., } \\
2014)\end{array}$ \\
\hline Atherosclerosis & $\begin{array}{l}\operatorname{miR}, 10 \mathrm{a}, \mathrm{miR} \\
\text { 143, miR, 145, } \\
\operatorname{miR}, 126, \operatorname{miR}, 33\end{array}$ & $\begin{array}{l}\text { (van Rooij and } \\
\text { Olson, 2012), } \\
\text { (Esteller, } \\
\text { 2011) }\end{array}$ \\
\hline $\begin{array}{l}\text { Cancer } \\
\text { Breast cancer } \\
\text { Lung cancer } \\
\text { Liver cancer }\end{array}$ & $\begin{array}{l}\operatorname{miR}, 125, \mathrm{miR} \\
145, \operatorname{miR}, 21, \mathrm{miR} \\
210 \\
\operatorname{miR}, 155, \text { let }-7 \mathrm{a} \\
\quad \operatorname{miR}, 29 \mathrm{~b}\end{array}$ & $\begin{array}{l}\text { (Li and } \\
\text { Kowdley, } \\
\text { 2012) }\end{array}$ \\
\hline Cardiac hypertrophy & $\begin{array}{l}\text { mik, } 21, \text { miR } \\
199 b\end{array}$ & $\begin{array}{c}\text { (van Rooij and } \\
\text { Olson, 2012) }\end{array}$ \\
\hline Metabolic disease & $\operatorname{miR}, 33, \operatorname{miR}, 122$ & $\begin{array}{l}\text { (Femández- } \\
\text { Hernando et } \\
\text { al., 2013) }\end{array}$ \\
\hline $\begin{array}{c}\text { Pulmonary } \\
\text { hypertension }\end{array}$ & $\begin{array}{l}\operatorname{miR}, 21, \operatorname{miR}, 145, \\
\operatorname{miR}, 210\end{array}$ & $\begin{array}{c}\text { (Zhou et al., } \\
2015 \text { ) }\end{array}$ \\
\hline Type 2 diabetes & $\begin{array}{l}\operatorname{miR}, 27 \mathrm{a}, \operatorname{miR} \\
29 \mathrm{a}, \operatorname{miR}, 125 \mathrm{a} \\
\operatorname{miR}, 222\end{array}$ & $\begin{array}{c}\text { (Ferland- } \\
\text { MoCollough at } \\
\text { al., 2010) }\end{array}$ \\
\hline
\end{tabular}


Many other miRNAs have been found either to be positive angiogenic factors (miR-27b, miR 130a, miR 210, miR 378, miR17-92 cluster, and miR let$7 \mathrm{f}$ ), or to have negative angiogenic effect (miR 15, miR 16, miR 20a, miR 20b, miR 24, miR 221, miR 222) (Hartmann and Thum, 2011; Urbich et al., 2008).

\subsubsection{MiRNAs that target renal function}

The kidneys play a critical role in maintenance of normal blood pressure through sodium homeostasis,blood volume, and rennin angiotensin aldosterone system (RAAS). MiRNAs play roles in both acute and chronic kidney diseases. The mechanism of action miRNAs at the kidneys were demonstrated by three methods:

a) Global depletion of miRNAs from specific cell types in kidneys by using conditional Dicer-knockout mouse models.

b) Analysis of differential miRNA expression in renal diseases to identify potential pathogenic miRNA species.

c) Study of miRNA regulation of specific genes that play pathogenic roles in renal disease (Bhatt et al., 2011).

Results from these studies showed that in certain Dicer knockout models of mice, pathological abnormalities of podocyte cells of the glomeruli was correlated with end stage renal disease and maintenance of blood pressure (Harvey et al., 2008). This mouse model clearly suggests that Dicer is a critical factor for the maintenance of podocyte homeostasis. It is suggested that the loss of miR-30 family miRNAs from podocytes may be responsible for the defect in the homoeostasis and function of podocytes in kidney (Agrawal et al., 2009).

\subsubsection{3. miRNAs that target the RAAS system of kidney}

The RAAS has a critical role in controlling BP through several enzymes, peptides, and receptors. For example, angiotensin II, a peptide hormone, has a vasoconstrictor effect and can release other hormones as aldosterone and vasopressin. A correlation between serum miRNA 155 and low risk of hypertension was demonstrated
(Martin et al., 2006). The release of angiotensin II is controlled post-transcriptionally by miRNA 155 . MiRNA 155binds to the angiotensin II coding gene, AT1, which inhibits its transcription (Martin et al., 2006). Another miRNA, miRNA 9 can decrease the hypertrophic effect of aldosterone in cardiac and vascular smooth muscle cells through suppressing myocardin expression (Wang et al., 2010).

A study of 850 miRNAs in renal tissue of hypertensive and healthy controls showed that reduced expression of miRNA 181a and miRNA 663 was associated with elevation of rennin mRNA expression (Marques et al., 2011). Studies also showed that 46 miRNAs had aberrant expression in hypertensive patients compared with healthy individuals. Among these, human cytomegalovirus-miR-UL112, miR-605, miR623, miRlet-7e, miR-516b, miR-600, kshv-miR-K12-6-3p, miR602 and miR-1252 were up-regulated, andmiR-296-5p, miR-133b, miR-625, miR-1236, miR518b, miR-1227, miR-615-5p, miR-18b, miR-1249, miR-3243p, ebvmiR-BART17-3p, ebv-miR-BART19-5p, kshvmiRK12-10a, kshv-miR-K12-10b, miR-4865p, miR30d, miR-664 and miR-634 21 were down regulated (Marques et al., 2015). Correlations were discovered between exercise and expression of certain miRNAs targeting the RAS genes in hypertensive patients. Other miRNAs as miR-130a are correlated to vascular remodeling which may be explained by the effect of RAAS system on the patho-physiology of vascular remodeling (Renna et al., 2013,Wu et al., 2011).

\subsubsection{4. microRNAs that target vascular smooth muscle cells}

Peripheral vascular resistance has a critical role in development of hypertension. Vascular smooth muscle cells (VSMCs) as a contractile factor can determine vascular tone and resistance. Proliferationof VSMCs in response to stress results in vascular remodeling, a correlating factor with essential hypertension (Feihl et al., 2008). Vasodilatation in response to essential hypertension was more frequent in mice with less VSMC synthesis. The synthesis of VSMCs was regulated with dicer.So, VSMC- specific deletion of dicer showed impairment of vascular system in mice models. Mice lacking miR-143 and miR-145were similar to that of the VSMC-specific Dicer knockout mice, showing an important role for VSMC differentiation and function (Albinsson and Sessa, 2011). 
Another miRNA, microRNA 21, located in arterial smooth muscle cells, has been found to be a critical regulator of VSMC proliferation, which decreased with miRNA 21 inhibition (Ji et al., 2007).

\section{2.miRNA let-7}

Let-7 was first discovered and well studied in Caenorhabditis elegans, in which it regulates developmental timing (Reinhart et al., 2000), larval stage 4-to-adult transition (Grosshans et al., 2005), and stage-specific neuromuscular tissue development (Frasch M., 2008). In the mouse, let-7 is involved in neural lineage specificity of embryonic stem cells and brain development (Wulczyn et al., 2006). Let-7 is involved in many physiological processes as development of nervous system, muscle formation, cell adhesion and gene regulation (Cao et al., 2016).

Let-7 is also involved in many pathological diseases as inhibition of the growth of tumor cells in lung and hepatocellular carcinoma (Ardekani and Naeini, 2010,Barh et al., 2010), and neurodegenerative diseases as Parkinson's disease(Leggio et al., 2017).

\subsubsection{Types of miRNA let-7 and diseases}

There are 13 mature subtypes of miRNA let-7 family which have been identified in humans, including mir let-7a-1, let-7a-2, let-7a-3,mir let-7b, mir let-7c, mir let-7d, mir let-7e, mir let-f-1, let-7f2, mir let-7g, mir let-7i, mir 98 and mir 202 (Fedorko et al., 2017).

.Exogenous let-7 over-expression was associated with antitumor efficacy in many human cancers (Guan et al., 2015). The let-7 miRNA family has been reported to regulate immune activation in various cell types. In human epithelial cells, let7 suppresses immune responses to pathogens by inhibition of Toll-like receptor 4 (TLR4), and down-regulation of let-7 restores immune activation (Chen et al., 2007). In mammalian macrophages exposed to pathogen invasion, let-7 controls the immune response via inhibition of the NFKB1 pathway or repression of cytokine expression (Kumar et al., 2015). Studies showed that the overexpression of miRNA let-7 family, including let- $7 \mathrm{a} / 7 \mathrm{~b} / 7 \mathrm{c} / 7 \mathrm{e}$ was correlated with hepatocellular carcinoma progression and poor prognosis (Shi et al., 2017). MicroRNA let-7a was studied with many diseases and was shown to suppresses breast cancer cell migration and invasion through down-regulation of C-C chemokine receptor type 7 (Kim et al., 2012). Subtypes of let-7a were studied separately with many types of tumors. MicroRNA Let-7a-1 was shown to be associated with colorectal cancer through inverse relationship between let-7a expression levels and the density of $\mathrm{T}$ cells in colorectal cancer tissue, which is positively associated with colorectal cancer-specific mortality (Dou et al., 2016).Lower expression levels of miRNA let-7a-1 and pituitary adenoma was studiedand revealed the role of let7a-1 as a tumor suppressor by targeting high mobility group AT-hook 2 (HMGA2)gene expression(Li et al., 2014).

Serum expression of let-7d and let-7e was different in patients with Crohn's disease. As a result, they are used as therapeutic biomarkers in patients with Crohn's disease(Fujioka et al., 2014).

Let-7i andlet-7f were significantly elevated in gastric cancer and serum let-7c was negatively correlated to pepsinogen $\mathrm{C}$ and its target gene, indicating that let-7 miRNA may be a potential biomarker for the diagnosis of gastric disease (Liu et al., 2015).

Let-7g induced increased expression of vascular endothelial growth factor-A (VEGF-A) and VEGF receptor-2, improving angiogenesis (Hsu et al, 2017). Other study suggested that miR-let-7g may serve as a potential therapeutic agent for treating atherosclerosis through inhibiting lectin-like oxLDL receptor (LOX-1) expression, which is expressed in VSMCs, vascular ECs and macrophages, and plays a critical role in the pathogenesis of atherosclerosis. Overexpression of LOX-1resulted in the significant promotion of proliferation and migration of human aortic smooth muscle cells (ASMCs), increasing the incidence of atherosclerosis (Liu et al., 2017).

Severe preeclampsia was correlated with up-regulation of miRNA 202-3p during the first trimester (Singh et al., 2017). MiR 202 may function as a tumor suppressor in endometrial adenocarcinoma (EAC) by targeting fork head box (FOXR2) oncogene, which may provide new insights into the molecular mechanism (Deng et al., 2017). 


\subsubsection{Biogenesis of let-7 and mechanism of action}

The biogenesis of let-7 is similar to that of other miRNAs. The first step in miRNA biogenesis is transcription from the miRNA transcription unit by RNA polymerase II to produce a primary transcript called pri-miRNA. The pri-miRNA is processed by the microprocessor complex containing an RNAse III-like enzyme, Drosha, and its cofactor, a doublestranded RNA binding protein, Dgcr8, to produce an approximately 60-70 nt pre-miRNA (precursor miRNA). The pre-miRNA is then transported to cytoplasm by exportin 5 (XPO5), in a RAN-GTP (ras- related nuclear protein-guanosine triphosphate complex) - dependent way, where it is cleaved by Dicer (a cytoplasmic RNAse III), to generate an imperfect miRNA: miRNA* duplex of approximately 21-24 nt. One of the strands (the "guide strand") from the duplex is then incorporated into Argonaute (Ago)-containing ribonucleoprotein (RNP) complex; the other strand (the passenger strand) is degraded.

However, there are cases in which both strands of the duplex are detected in the cell. The miRNAAgoRNP complex causes post-transcriptional regulation of genes, in which miRNA is used as a target to guide the complex to the specific mRNA. Many factors are implicated in regulation of let-7 synthesis (Figure 4).

1. Some factors have inhibitory effect as Lin 28 gene and Lin28B gene (Reinhart et al., 2000).They act as post-transcriptional repressors of let-7 biogenesis. Many hypotheses suggested the mechanism either by binding to the loop portion of the pri-let-7 hairpin and the stem of pre-let-7 to inhibit the binding of Drosha or Dicer, or by targeting pre-let-7 through its degradation. When the DNA of the genes that are responsible for miRNAs synthesis are methylated, the expression of let-7 is affected (Lopez-Serra and Esteller, 2011).

2. Another inhibitory complex, is nuclear factor (NF) 90 andNF 45 which showed a higher affinity to pri-miRNA-let-7. They inhibit binding to Drosha- DGCR8 complex (Sakamoto et al., 2009).

3. Interleukin-6 (IL-6), nuclear factor kappa-lightchain-enhancer of activated $\mathrm{B}$ cells $\left(\mathrm{NF}_{\mathrm{k}} \mathrm{B}\right)$, insulin

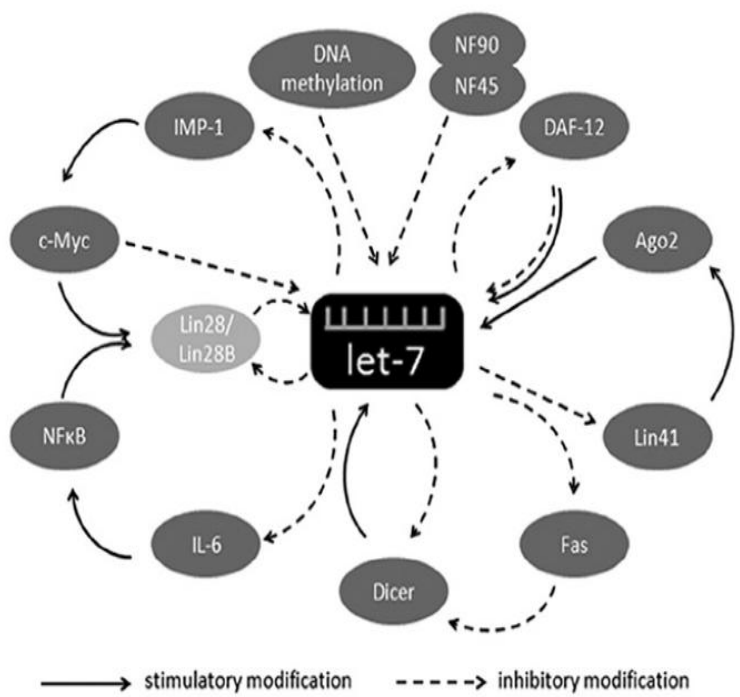

Figure 4. Factors that regulate miRNA let-7 expression. IL-6; Interleukin-6, Ago2; Argonate 2, Lin28 and Lin28B; post-transcriptional repressors genes, NF 90; nuclear factor90, NF45; nuclear factor $45, \mathrm{NF}_{\mathrm{k}} \mathrm{B}$; nuclear factor kappa-light-chain-enhancer of activated B cells, IMP1; insulin like growth factor II mRNA binding protein 1, c-Myc; oncogene, DAF-12; nuclear hormone receptor (Wang et al., 2012b).

like growth factor II mRNA binding protein 1(IMP1), and oncogene c-Myc suppress miRNA let-7 synthesis either directly or indirectly through regulating Lin 28 expression as illustrated in (figure 4) (Barh et al., 2010; Psathas and Thomas-Tikhonenko, 2014; Wang et al., 2012a; Wei et al., 2016b)

4. Ago2, Dicer, and a nuclear hormone receptor (DAF12), stimulatory factors which activate let-7 biogenesis, are able to directly regulate the transcription of let-7 positively or negatively without the activity of Lin 28 (Diederichs and Haber, 2007; Forman et al., 2008; Hammell et al., 2009) .

\subsubsection{Implication of let-7 in cardiovascular disease and essential hypertension}

MiRNA let-7 is bound in endothelial cells (ECs) and directly targets several angiogenesis-related factors, making let-7 a miR regulator of angiogenesis (Zhao and Popel, 2015). Studies have also suggested that let-7 may contribute to atherosclerotic disease by regulating tumor necrosis factor- $\alpha$ (TNF- $\alpha$ ) (Katayama et al., 2015), glucose metabolism (Zhu et al., 2011), and inflammatory reactions (Liao et al., 2014). 
miRNA let-7e was upregulated in Hashimoto's disease (Kagawa et al., 2016). It is used as plasma marker in metabolic dysfunction (Krause et al., 2015), and serum expression can be used in the prognosis of lung cancer (Zhu et al., 2014) and osteoarthritis (Beyer et al., 2015). Overexpression of microRNA let-7e correlates with disease progression and poor prognosis in hepatocellular carcinoma (Shi et al., 2017).

\subsection{Other miRNAs that were recently studied with essential hypertension}

\subsection{1. $\quad$ MiRNA 296}

MiRNA 296 expression is both up- or downregulated in different metastatic diseases. In parathyroid carcinomas and colon cancer miRNA 296 was down-regulated (Corbetta et al., 2010, Shivapurkar et al., 2013), but it was up-regulated in esophageal carcinomas and immortalized cancer cells (Hong et al., 2010, Yoon et al., 2011). MiRNA 296 functions as a tumor suppressive factor in lung carcinoma(Vaira et al., 2013), hepatocellular carcinoma(Vaira et al., 2012), and prostate cancer (Wei et al., 2011).

MiR 296 was suggested to regulate blood pressure through down-regulation of the Human with-nolysine kinase-4 (hWNK4) protein at the posttranscriptional level. The hWNK4 protein is a member of the serine-threonine protein kinase family and it is an important factor involved in patho-physiological progress of hypertension through regulating ion channels, co-transporters, altering the balance of $\mathrm{NaCl}$ reabsorption and $\mathrm{K}^{+}$ secretion in the distal part of nephron, and electrolyte homeostasis(Mao et al., 2010).Different studies have reported miRNA 296 to be either upor down-regulated in hypertensive patients (Cengiz et al., 2015, Li et al., 2011).

\subsubsection{MiRNA 605}

miRNA 605 was upregulated in hypertensive patients, and has been confirmed by microarray and quantitative real-time polymerase chain reaction (qPCR) (Ali et al., 2016). It is not clear how miRNA 605 affects blood pressure. It is hypothesized that there is an association between miRNA 605 and transcription of Syndecan 4 (SDC4) gene. SDC4 encodes the protein syndecan-
4, a heparan sulfate proteoglycan whose overproduction was associated with elevated BMI, lipid profile and elevated blood pressure (Rose et al., 2015). MiRNA 605 expression was reported to be up-regulated in blood of patients with stroke (Yuan et al., 2016).

A polymorphism of miRNA 605 gene was associated with increased risk of squamous cell carcinoma (Miao et al., 2016), Li-Fraumeni syndrome (Id Said and Malkin, 2015), prostate cancer (Huang et al., 2014), and gastrointestinal cancer (Zhang et al., 2012). MiRNA 605 was downregulated in melanoma cell lines and suppressed melanoma cell growth both in vitro and in vivo. Bioinformatics analysis suggested the mechanism by which the miRNA 605 works. Inositol polyphosphate 4-phosphatase type II (INPP4B) gene is a target of miR 605 and the inhibition of INPP4B is required for the suppressive role of miR605 on melanoma cell growth. Thus, miR605 functions as a tumor suppressor by negatively regulating INPP4B in melanoma (Chen et al., 2017).

\subsubsection{MiRNA 623}

MiRNA 623 was upregulated in patients with cardiovascular diseases (Ali et al., 2016). MiRNA 623 and miRNA 605 were overexpressed in patients with essential hypertension, but serum expression did not correlate with elevated systolic and diastolic blood pressure. Rather, serum expression of both miRNAs correlated with dyslipidemia, indicating that they are not directly associated with essential hypertension but associated with the dyslipidemia that frequently accompanies the disease (Badawy Et al., 2018). MiRNA 623 was found to inhibit lung adenocarcinoma through decreasing expression of target gene Ku80 and metalloproteinases (MMPs), which promote tumor invasion, metastasis, and angiogenesis (Wei et al., 2016a).

\section{Conclusion}

The stability of miRNAs in biological fluids and resistance to degradation allow them to be easily detected and measured. There is a strong association between circulating miRNAs, as biological markers, and polygenic diseases as essential hypertension.

\section{Conflict of interest}

The authors report no declaration of conflict of interest. 


\section{References}

Agrawal, R., Tran, U., and Wessely, O., 2009. The miR-30 miRNA family regulates Xenopuspronephros development and targets the transcription factor Xlim1/Lhx1. Development. 136, 3927-3936.

Albinsson, S., and Sessa, W.C., 2011. Can microRNAs control vascular smooth muscle phenotypic modulation and the response to injury?.Physiol Genomics. 43, 529-533.

Ali, S.S., Kala, C., Abid, M., Ahmad, N., Sharma, U.S., and Khan, N.A., 2016. Pathological microRNAs in acute cardiovascular diseases and microRNA therapeutics. J Acute Dis. 5, 9-15.

Ardekani, A.M., and Naeini, M.M., 2010. The Role of MicroRNAs in Human Diseases. Avicenna $\mathbf{J}$ Med Biotechnol. 2, 161-179.

Badawy, H.K., Abo-Elmatty, D.M., and Mesbah, N.M., 2018. Association between serum microRNA-605 and microRNA-623 expression and essential hypertension in Egyptian patients. Meta Gene. 16, 62-65.

Barh, D., Malhotra, R., Ravi, B., and Sindhurani, P., 2010. MicroRNA let-7: an emerging nextgeneration cancer therapeutic. Curr Oncol. 17, 7080 .

Bartel, D.P., 2004. MicroRNAs: genomics, biogenesis, mechanism, and function. Cell. 116, 281-297.

Bartel, D.P., 2009. MicroRNAs: target recognition and regulatory functions. Cell. 136, 215-233.

Bhatt, K., Mi, Q.S., and Dong, Z., 2011. microRNAs in kidneys: biogenesis, regulation, and pathophysiological roles. Am J Physiol Renal Physiol. 300, F602-610.

Buchan, J.R., and Parker, R., 2007. Molecular biology. The two faces of miRNA. Science. 318, 1877-1878.

Cao, D.D., Li, L., and Chan, W.Y., 2016. MicroRNAs: Key Regulators in the central nervoussystem and their implication in neurological diseases. Int J Mol Sci. 17, 842.
Cengiz, M., Karatas, O.F., Koparir, E., Yavuzer, S., Ali, C., Yavuzer, H., Kirat, E., Karter, Y., and Ozen, M., 2015. Differential expression of hypertensionassociated microRNAs in the plasma of patients with white coat hypertension. Medicine. 94, e693.

Chen, L., Cao, Y., Rong, D., Wang, Y., and Cao, Y., 2017. MicroRNA-605 functions as a tumor suppressor by targeting INPP4B in melanoma. Oncol Rep. 38, 1276-1286.

Chen, X.M., Splinter, P.L., O'Hara, S.P., and LaRusso, N.F., 2007. A cellular micro-RNA, let-7i, regulates Toll-like receptor 4 expression and contributes to cholangiocyte immune responses against Cryptosporidium parvum infection. J Biol Chem. 282, 28929-28938.

Corbetta, S., Vaira, V., Guarnieri, V., Scillitani, A., Eller-Vainicher, C., Ferrero, S., Vicentini, L., Chiodini, I., Bisceglia, M., Beck-Peccoz, P., et al., 2010. Differential expression of microRNAs in human parathyroid carcinomas compared with normal parathyroid tissue. Endocr Relat Cancer. 17, 135-146.

Deng, X., Hou, C., Liang, Z., Wang, H., Zhu, L., and $\mathrm{Xu}$, H., 2017. miR-202 suppresses cell proliferation by targeting FOXR2 in endometrial adenocarcinoma. Dis Markers. 2827435.

Diederichs, S., and Haber, D.A., 2007. Dual role for argonautes in microRNA processing and posttranscriptional regulation of microRNA expression. Cell. 131, 1097-1108.

Dou, R., Nishihara, R., Cao, Y., Hamada, T., Mima, K., Masuda, A., Masugi, Y., Shi, Y., Gu, M., Li, W., et al., 2016. MicroRNA let-7, T Cells, and Patient Survival in Colorectal Cancer. Cancer Immunol Res. 4, 927-935.

El-Hefnawy, T., Raja, S., Kelly, L., Bigbee, W.L., Kirkwood, J.M., Luketich, J.D., and Godfrey, T.E., 2004. Characterization of amplifiable, circulating RNA in plasma and its potential as a tool for cancer diagnostics. Clin Chem. 50, 564-573.

Esteller, M., 2011. Non-coding RNAs in human disease. Nature reviews. Genetics. 12, 861-874.

Farazi, T.A., Juranek, S.A., and Tuschl, T., 2008. The growing catalog of small RNAs and their association with distinct Argonaute/Piwi family members. Development. 135, 1201-1214. 
Fedorko, M., Juracek, J., Stanik, M., Svoboda, M., Poprach, A., Buchler, T., Pacik, D., Dolezel, J., and Slaby, O., 2017. Detection of let-7 miRNAs in urine supernatant as potential diagnostic approach in nonmetastatic clear-cell renal cell carcinoma. Biochem Med. 27, 411-417.

Feihl, F., Liaudet, L., Levy, B.I., and Waeber, B., 2008. Hypertension and microvascular remodelling. Cardio vasc Res. 78, 274-285.

Ferland-McCollough, D., Ozanne, S.E., Siddle, K., Willis, A.E., and Bushell, M., 2010. The involvement of microRNAs in Type 2 diabetes. Biochem Soc Trans. 38, 1565-1570.

Fernandez-Hernando, C., Ramirez, C.M., Goedeke, L., and Suarez, Y., 2013. MicroRNAs in metabolic disease. Arterioscler Thromb Vasc Biol. 33, 178185.

Filipowicz, W., 2005. RNAi: the nuts and bolts of the RISC machine. Cell. 122, 17-20.

Forman, J.J., Legesse-Miller, A., and Coller, H.A., 2008. A search for conserved sequences in coding regions reveals that the let-7 microRNA targets Dicer within its coding sequence. Proc Natl Acad Sci U S A. 105, 14879-14884.

Frasch, M., 2008. A matter of timing: microRNAcontrolled temporal identities in worms and flies. Genes Dev. 22, 1572-1576.

Fujioka, S., Nakamichi, I., Esaki, M., Asano, K., Matsumoto, T., and Kitazono, T. 2014. Serum microRNA levels in patients with Crohn's disease during induction therapy by infliximab. J Gastroenterol Hepatol. 29, 1207-1214.

Fukuda, T., Yamagata, K., Fujiyama, S., Matsumoto, T., Koshida, I., Yoshimura, K., Mihara, M., Naitou, M., Endoh, H., Nakamura, T., et al., 2007. DEAD-box RNA helicase subunits of the Drosha complex are required for processing of rRNA and a subset of microRNAs. Nat Cell Biol. 9, 604-611.

Gregory, R.I., Yan, K.P., Amuthan, G., Chendrimada, T., Doratotaj, B., Cooch, N., and Shiekhattar, R., 2004. The Microprocessor complex mediates the genesis of microRNAs. Nature. 432, 235-240.
Grosshans, H., Johnson, T., Reinert, K.L., Gerstein, M., and Slack, F.J., 2005. The temporal patterning microRNA let-7 regulates several transcription factors at the larval to adult transition in C. elegans. Dev Cell. 8, 321-330.

J, G., S, G., and M, L., 2015. Let-7 Family miRNAs Represent Potential Broad-Spectrum Therapeutic Molecules for Human Cancer. J Genet Syndr Gene Ther. 6, 271

Ha, T.-Y., 2011. MicroRNAs in Human Diseases: From Cancer to Cardiovascular Disease. Immune Netw. 11, 135-154.

Hammell, C.M., Karp, X., and Ambros, V., 2009. A feedback circuit involving let-7-family miRNAs and DAF-12 integrates environmental signals and developmental timing in Caenorhabditis elegans. Proc Natl Acad Sci U S A. 106, 18668-18673.

Hartmann, D., and Thum, T., 2011. MicroRNAs and vascular (dys) function. Vasc pharmacol. 55, 92-105.

Harvey, S.J., Jarad, G., Cunningham, J., Goldberg, S., Schermer, B., Harfe, B.D., McManus, M.T., Benzing, T., and Miner, J.H., 2008. Podocyte-specific deletion of dicer alters cytoskeletal dynamics and causes glomerular disease. J Am Soc Nephrol. 19, 2150-2158.

Hedley, P.L., Carlsen, A.L., Christiansen, K.M., Kanters, J.K., Behr, E.R., Corfield, V.A., and Christiansen, M., 2014.

MicroRNAs in cardiac arrhythmia: DNA sequence variation of MiR-1 and MiR-133A in long QT syndrome. Scand J Clin Lab Invest. 74, 485-491.

Hong, L., Han, Y., Zhang, H., Li, M., Gong, T., Sun, L., Wu, K., Zhao, Q., and Fan, D., 2010. The prognostic and chemotherapeutic value of miR-296 in esophageal squamous cell carcinoma. Ann Surg. 251, 1056-1063.

Hsu, P.Y., Hsi, E., Wang, T.M., Lin, R.T., Liao, Y.C., and Juo, S.H., 2017. MicroRNA let-7g possesses a therapeutic potential for peripheral artery disease. $\mathrm{J}$ cell mol med. 21, 519-529.

Huang, S.P., Levesque, E., Guillemette, C., Yu, C.C., Huang, C.Y., Lin, V.C., Chung, I.C., Chen, L.C., Laverdiere, I., Lacombe, L., et al., 2014. Genetic variants in microRNAs and microRNA target sites predict biochemical recurrence after radical prostatectomy in localized prostate cancer. Int J Cancer. 


\section{5, 2661-2667.}

Id Said, B., and Malkin, D., 2015. A functional variant in miR-605 modifies the age of onset in $\mathrm{Li}$ Fraumeni syndrome. Cancer Genet. 208, 47-51.

Ji, R., Cheng, Y., Yue, J., Yang, J., Liu, X., Chen, H., Dean, D.B., and Zhang, C., 2007. MicroRNA expression signature and antisense-mediated depletion reveal an essential role of MicroRNA in vascular neointimal lesion formation. Circ Res. 100, 1579-1588.

Kagawa, T., Watanabe, M., Inoue, N., Otsu, H., Saeki, M., Katsumata, Y., Takuse, Y., and Iwatani, Y., 2016. Increases of microRNA let-7e in peripheral blood mononuclear cells in Hashimoto's disease. Endocri J. 63, 375-380.

Katayama, M., Sjogren, R.J., Egan, B., and Krook, A., 2015. miRNA let-7 expression is regulated by glucose and TNF-alpha by a remote upstream promoter. Biochem J. 472, 147-156.

Kim, D.H., and Rossi, J.J., 2007. Strategies for silencing human disease using RNA interference. Nat Rev Genet. 8, 173-184.

Kim, S.-J., Shin, J.-Y., Lee, K.-D., Bae, Y.-K., Sung, K.W., Nam, S.J., and Chun, K.-H., 2012. MicroRNA let-7a suppresses breast cancer cell migration and invasion through downregulation of C-C chemokine receptor type 7. Breast Cancer Res. 14, R14-R14.

Knight, S.W., and Bass, B.L., 2001. A role for the RNase III enzyme DCR-1 in RNA interference and germ line development in Caenorhabditis elegans. Science. 293, 2269-2271.

Kozomara, A., and Griffiths-Jones, S., 2011. miRBase: integrating microRNA annotation and deep-sequencing data. Nucleic acids Res. 39, D152D157.

Krause, B.J., Carrasco-Wong, I., Dominguez, A., Arnaiz, P., Farias, M., Barja, S., Mardones, F., and Casanello, P., 2015. Micro-RNAs Let7e and 126 in Plasma as Markers of Metabolic Dysfunction in 10 to 12 Years Old Children. PloS One. 10, e0128140.

Kumar, M., Sahu, S.K., Kumar, R., Subuddhi, A., Maji, R.K., Jana, K., Gupta, P., Raffetseder, J., Lerm, M., Ghosh, Z., et al., 2015. MicroRNA let-7 modulates the immune response to Mycobacterium tuberculosis infection via control of A20, an inhibitor of the NF-kappaB pathway. Cell Host \& Microbe. 17, 345-356.

Lagos-Quintana, M., Rauhut, R., Lendeckel, W., and Tuschl, T., 2001. Identification of novel genes coding for small expressed RNAs. Science. 294, 853-858.

Lagos-Quintana, M., Rauhut, R., Yalcin, A., Meyer, J., Lendeckel, W., and Tuschl, T., 2002. Identification of tissue-specific microRNAs from mouse. Cur Biol. 12, 735-739.

Landmesser, U., and Drexler, H., 2007. Endothelial function and hypertension. Cur opin Cardiol. 22, 316320.

Lee, R.C., and Ambros, V., 2001. An extensive class of small RNAs in Caenorhabditis elegans. Science. 294, 862-864.

Lee, R.C., Feinbaum, R.L., and Ambros, V., 1993. The C. elegans heterochronic gene lin-4 encodes small RNAs with antisense complementarity to lin-14. Cell. 75, 843-854.

Leggio, L., Vivarelli, S., L'Episcopo, F., Tirolo, C., Caniglia, S., Testa, N., Marchetti, B., and Iraci, N., 2017. microRNAs in Parkinson's Disease: From Pathogenesis to Novel Diagnostic and Therapeutic Approaches. Int JMol Sci. 18, 2698.

Li, S., Zhu, J., Zhang, W., Chen, Y., Zhang, K., Popescu, L.M., Ma, X., Lau, W.B., Rong, R., Yu, X., et al., 2011. Signature microRNA expression profile of essential hypertension and its novel link to human cytomegalovirus infection. Circulation. 124, 175-184.

Li, X.-H., Wang, E.L., Zhou, H.-M., Yoshimoto, K., and Qian, Z.R., 2014. MicroRNAs in Human Pituitary Adenomas. Int J Endocrinol. 2014, 435171.

Li, Y., and Kowdley, K.V., 2012. MicroRNAs in common human diseases. Genomics, proteomics \& bioinformatics. 10, 246-253.

Liao, Y.C., Wang, Y.S., Guo, Y.C., Lin, W.L., Chang, M.H., and Juo, S.H., 2014. Let-7g improves multiple endothelial functions through targeting transforming growth factor-beta and SIRT-1 signaling. J Am Coll Cardiol. 63, 1685-1694.

Liu, M., Tao, G., Liu, Q., Liu, K., and Yang, X., 2017. 
MicroRNA let-7g alleviates atherosclerosis via the targeting of LOX-1 in vitro and in vivo. Int $\mathbf{J}$ Mol Med. 40, 57-64.

Liu, W.J., Xu, Q., Sun, L.P., Dong, Q.G., He, C.Y., and Yuan, Y., 2015. Expression of serum let-7c, let-7i, and let-7f microRNA with its target gene, pepsinogen $\mathrm{C}$, in gastric cancer and precancerous disease. Tumour Biol. 36, 3337-3343.

Lopez-Serra, P., and Esteller, M., 2011. DNA methylation-associated silencing of tumorsuppressor microRNAs in cancer. Oncogene. 31, 1609.

Mao, J., Li, C., Zhang, Y., Li, Y., and Zhao, Y., 2010. Human with-no-lysine kinase-4 3'-UTR acting as the enhancer andbeing targeted by miR296. Int J Biochem Cell Biol. 42, 1536-1543.

Marques, F.Z., Booth, S.A., and Charchar, F.J., 2015. The emerging role of non-coding RNA in essential hypertension and blood pressure regulation. J Hum Hypertens. 29, 459-467.

Marques, F.Z., Campain, A.E., Tomaszewski, M., Zukowska-Szczechowska, E., Yang, Y.H., Charchar, F.J., and Morris, B.J., 2011. Gene expression profiling reveals renin mRNA overexpression in human hypertensive kidneys and a role for microRNAs. Hypertension. 58, 10931098.

Martin, M.M., Lee, E.J., Buckenberger, J.A., Schmittgen, T.D., and Elton, T.S., 2006. MicroRNA-155 regulates human angiotensin II type 1 receptor expression in fibroblasts. J Biol Chem. 281, 18277-18284.

Martinez, J., Patkaniowska, A., Urlaub, H., Luhrmann, R., and Tuschl, T., 2002. Singlestranded antisense siRNAs guide target RNA cleavage in RNAi. Cell. 110, 563-574.

Miao, L., Wang, L., Zhu, L., Du, J., Zhu, X., Niu, Y., Wang, R., Hu, Z., Chen, N., Shen, H., et al., 2016. Association of microRNA polymorphisms with the risk of head and neck squamous cell carcinoma in a Chinese population: a case-control study. Chin J Cancer. 35, 77.

Miska, E.A., Alvarez-Saavedra, E., Abbott, A.L., Lau, N.C., Hellman, A.B., McGonagle, S.M.,
Bartel, D.P., Ambros, V.R., and Horvitz, H.R., 2007. Most Caenorhabditis elegans microRNAs Are Individually Not Essential for Development or Viability. PLoS Genet. 3, e215.

Nadar, S.K., Tayebjee, M.H., Messerli, F., and Lip, G.Y., 2006. Target organ damage in hypertension: pathophysiology and implications for drug therapy. Curr Pharm Des. 12, 1581-1592.

Nemecz, M., Alexandru, N., Tanko, G., and Georgescu, A., 2016. Role of MicroRNA in Endothelial Dysfunction and Hypertension. Curr Hypertens Rep. 18, 87.

Okada, C., Yamashita, E., Lee, S.J., Shibata, S., Katahira, J., Nakagawa, A., Yoneda, Y., and Tsukihara, T., 2009. A high-resolution structure of the pre-microRNA nuclear export machinery. Science. 326, 1275-1279.

Pasquinelli, A.E., Reinhart, B.J., Slack, F., Martindale, M.Q., Kuroda, M.I., Maller, B., Hayward, D.C., Ball, E.E., Degnan, B., Müller, P., et al., 2000. Conservation of the sequence and temporal expression of let-7 heterochronic regulatory RNA. Nature. 408, 86.

Psathas, J.N., and Thomas-Tikhonenko, A., 2014. MYC and the Art of MicroRNA Maintenance. Cold Spring Harb Perspect Med. 4, 10.

Reinhart, B.J., Slack, F.J., Basson, M., Pasquinelli, A.E., Bettinger, J.C., Rougvie, A.E., Horvitz, H.R., and Ruvkun, G., 2000. The 21-nucleotide let-7 RNA regulates developmental timing in Caenorhabditis elegans. Nature. 403, 901-906.

Renna, N.F., de lasHeras, N., and Miatello, R.M., 2013. Pathophysiology of Vascular Remodeling in Hypertension. Int J Hypertens. 2013, 808353.

Romaine, S.P., Charchar, F.J., Samani, N.J., and Tomaszewski, M., 2016. Circulating microRNAs and hypertension--from new insights into blood pressure regulation to biomarkers of cardiovascular risk. Curr Opin Pharmacol. 27, 1-7.

Romaine, S.P.R., Tomaszewski, M., Condorelli, G., and Samani, N.J., 2015. MicroRNAs in cardiovascular disease: an introduction for clinicians. Heart. 0, 1-8.

Rose, G., Crocco, P., De Rango, F., Corsonello, A., 
Lattanzio,F., De Luca, M., and Passarino, G., 2015. Metabolism and successful aging: Polymorphic variation of syndecan-4 (SDC4) gene associate with longevity and lipid profile in healthy elderly Italian subjects. Mech Ageing Dev. 150, 27-33.

Sabatel, C., Malvaux, L., Bovy, N., Deroanne, C., Lambert, V., Gonzalez, M.L., Colige, A., Rakic, J.M., Noel, A., Martial, J.A., et al., 2011. MicroRNA-21 exhibits antiangiogenic function by targeting RhoB expression in endothelial cells. PloS One. 6, e16979.

Sakamoto, S., Aoki, K., Higuchi, T., Todaka, H., Morisawa, K., Tamaki, N., Hatano, E., Fukushima, A., Taniguchi, T., and Agata, Y., 2009. The NF90NF45 complex functions as a negative regulator in the microRNA processing pathway. Mol Cell Biol. 29, 3754-3769.

Shi, W., Zhang, Z., Yang, B., Guo, H., Jing, L., Liu, T., Luo, Y., Liu, H., Li, Y., and Gao, Y., 2017. Overexpression of microRNA let-7 correlates with disease progression and poor prognosis in hepatocellular carcinoma. Medicine. 96, e7764e7764.

Singh, K., Williams, J., 3rd, Brown, J., Wang, E.T., Lee, B., Gonzalez, T.L., Cui, J., Goodarzi, M.O., and Pisarska, M.D., 2017. Up-regulation of microRNA-202-3p in first trimester placenta of pregnancies destined to develop severe preeclampsia, a pilot study. Pregnancy hypertens. 10, 7-9.

Shivapurkar, N., Mikhail, S., Navarro, R., Bai, W., Marshall, J., Hwang, J., Pishvaian, M., Wellstein, A., and He, A.R., 2013. Decrease in blood miR296 predicts chemotherapy resistance and poor clinical outcome in patients receiving systemic chemotherapy for metastatic colon cancer. Int $\mathbf{J}$ Colorectal Dis. 28, 887.

Thum, T., Galuppo, P., Wolf, C., Fiedler, J., Kneitz, S., van Laake, L.W., Doevendans, P.A., Mummery, C.L., Borlak, J., Haverich, A., et al., 2007. MicroRNAs in the Human Heart. A Clue to Fetal Gene Reprogramming in Heart Failure. Circulation. 116, 258-267.

Urbich, C., Kuehbacher, A., and Dimmeler, S., 2008. Role of microRNAs in vascular diseases, inflammation, and angiogenesis. Cardiovasc Res. $79,581-588$.

Vaira, V., Faversani, A., Dohi, T., Montorsi, M., Augello, C., Gatti, S., Coggi, G., Altieri, D.C., and Bosari, S., 2012. miR-296 regulation of a cell polarity-cell plasticity module controls tumor progression. Oncogene. 31, 27-38.

Vaira, V., Faversani, A., Martin, N.M., Garlick, D.S., Ferrero, S., Nosotti, M., Kissil, J.L., Bosari, S., and Altieri, D.C., 2013.Regulation of lung cancer metastasis by Klf4-Numb-like signaling. Cancer Res. 73, 2695-2705.

vanRooij, E., and Olson, E.N., 2012. MicroRNA therapeutics for cardiovascular disease: opportunities and obstacles. Nat Rev Drug discov. $11,860-872$.

Vickers, K.C., Palmisano, B.T., Shoucri, B.M., Shamburek, R.D., and Remaley, A.T., 2011. MicroRNAs are transported in plasma and delivered to recipient cells by high-density lipoproteins. Nat Cell Biol. 13, 423-433.

Wang, D.J., Legesse-Miller, A., Johnson, E.L., and Coller, H.A., 2012a. Regulation of the let-7a-3 Promoter by NF-кB. PloS One. 7, e31240.

Wang, K., Long, B., Zhou, J., and Li, P.F., 2010. miR-9 and NFATc3 regulate myocardin in cardiac hypertrophy. J Biol Chem. 285, 11903-11912.

Wang, S., Aurora, A.B., Johnson, B.A., Qi, X., McAnally, J., Hill, J.A., Richardson, J.A., BasselDuby, R., and Olson, E.N., 2008. The endothelialspecific microRNA miR-126 governs vascular integrity and angiogenesis. Dev Cell. 15, 261-271.

Wang, X., Cao, L., Wang, Y., Wang, X., Liu, N., and You, Y., 2012b. Regulation of let-7 and its target oncogenes (Review). OncolLett. 3, 955-960.

Weber, J.A., Baxter, D.H., Zhang, S., Huang, D.Y., Huang, K.H., Lee, M.J., Galas, D.J., and Wang, K., 2010. The microRNA spectrum in 12 body fluids. Clin Chem. 56, 1733-1741.

Wei, J.J., Wu, X., Peng, Y., Shi, G., Basturk, O., Yang, X., Daniels, G., Osman, I., Ouyang, J., Hernando, E., et al., 2011. Regulation of HMGA1 expression by microRNA-296 affects prostate cancer growth and invasion. Clin Cancer Res. 17, 
1297-1305.

Wei, S., Zhang, Z.-y., Fu, S.-1., Xie, J.-g., Liu, X.s., Xu, Y.-j., Zhao, J.-p., and Xiong, W.-n., 2016a. Hsa-miR-623 suppresses tumor progression in human lung adenocarcinoma. Cell Death Dis. 7, e2388.

Wei, Y.B., Liu, J.J., Villaescusa, J.C., Aberg, E., Brene, S., Wegener, G., Mathe, A.A., and Lavebratt, C., 2016b. Elevation of Il6 is associated with disturbed let-7 biogenesis in a genetic model of depression. Transl Psychiatry. 6, e869.

Wu, W.H., Hu, C.P., Chen, X.P., Zhang, W.F., Li, X.W., Xiong, X.M., and Li, Y.J., 2011. MicroRNA-130a mediates proliferation of vascular smooth muscle cells in hypertension. Am J Hypertens. 24, 1087-1093.

Wulczyn, F.G., Smirnova, L., Rybak, A., Brandt, C., Kwidzinski, E., Ninnemann, O., Strehle, M., Seiler, A., Schumacher, S., and Nitsch, R., 2007. Post-transcriptional regulation of the let-7 microRNA during neural cell specification. FASEB J. 21, 415-426.

Yoon, A.R., Gao, R., Kaul, Z., Choi, I.K., Ryu, J., Noble, J.R., Kato, Y., Saito, S., Hirano, T., Ishii, T., et al., 2011. MicroRNA-296 is enriched in cancer cells and downregulates p21WAF1 mRNA expression via interaction with its 3 ' untranslated region. Nucleic Acids Res. 39, 8078-8091.

Yuan, Y., Kang, R., Yu, Y., Liu, J., Zhang, Y., Shen, C., Wang, J., Wu, P., Shen, C., and Wang, Z., 2016. Crosstalk between miRNAs and their regulated genes network in stroke. Sci Rep. 6, 20429.
Zeng, Y., and Cullen, B.R. , 2003. Sequence requirements for micro RNA processing and function in human cells. RNA. 9, 112-123.

Zhang, C., 2009. Novel functions for small RNA molecules. Curr Opin Mol Ther. 11, 641-651.

Zhang, M.W., Jin, M.J., Yu, Y.X., Zhang, S.C., Liu, B., Jiang, X., Pan, Y.F., Li, Q.I., Ma, S.Y., and Chen, K., 2012. Associations of lifestyle-related factors, hsa-miR-149 and hsa-miR-605 gene polymorphisms with gastrointestinal cancer risk. Mol Carcinog. 51, E21-31.

Zhao, C., and Popel, A.S., 2015. Computational Model of MicroRNA Control of HIF-VEGF Pathway: Insights into the Pathophysiology of Ischemic Vascular Disease and Cancer. PLoS Comput Biol. 11, e1004612.

Zhou, G., Chen, T., and Raj, J.U., 2015. MicroRNAs in pulmonary arterial hypertension. Am J Respir Cell Mol Biol. 52, 139-151.

Zhu, H., Shyh-Chang, N., Segre, A.V., Shinoda, G., Shah, S.P., Einhorn, W.S., Takeuchi, A., Engreitz, J.M., Hagan, J.P., Kharas, M.G., et al., 2011. The Lin28/let-7 axis regulates glucose metabolism. Cell. 147, 81-94.

Zhu, W.Y., Luo, B., An, J.Y., He, J.Y., Chen, D.D., Xu, L.Y., Huang, Y.Y., Liu, X.G., Le, H.B., and Zhang, Y.K., 2014. Differential expression of miR$125 \mathrm{a}-5 \mathrm{p}$ and let-7e predicts the progression and prognosis of non-small cell lung cancer. Cancer Invest. 32, 394-401. 